\title{
Analysis of Agricultural Rice Production in Jambi: Study of Acreage Response Under Price Policy Program
}

\author{
Edison \\ Faculty of Agriculture University of Jambi \\ E-mail: ediedison950@yahoo.co.id
}

\begin{abstract}
The main objective of this research were to analyze the impact of some agricultural investments in rice production, The increasing trend of rice production in Jambi during the years of study (1986-2010) has been resulted from considerable increase in government improving policy programs, such as support price, and input subsidy programs. The variations of acreage, yield, and output have been affected also by the price of output and input such as fertilizer. The more effectiveness between price support policy and input subsidy policy depend on the higher magnitude between the significant coefficients of these two variables. The first policy implication from the findings of this study is that the price support policy is more effective and efficient to increase the acreage. The effect of government support prices for rice is very important in analyzing the acreage response. Since the role of government support prices in this new environment has received very much attention in policy implications. A method of measuring price expectation for analyzing acreage response is used when the influence of price support and market phenomena varies with market conditions. It assumes that the effect of changes in government policies because similar programs for acreage control and price support are likely form of future policies. A method of evaluating support, and acreage restriction is developed and tested to see the impact of changing government programs. The results show that when the support price is much below the expected market price, the truncation effect is negligible and the price support program has only a limited impact on acreage decisions. Alternatively, as the support price levels, the truncation effects become larger, and the resulting impact on acreage decisions is more pronounced.
\end{abstract}

Keywords - acreage response; rice production; price policy program.

\section{INTRODUCTION}

In a mixed economy such as Jambi's, rice prices are formed in markets and reflect a combination of government interventions and basic market forces. Rice prices have nearly always been heavily influenced by direct policy interventions, and hence the acreage response decision (1) Pearson et al. 1991). The government can also affect the basic market forces that influence commodity price information. According to Kolawole et al. (2), price policy for inputs directly affects the profitability of growing crops, and hence the supplies available in the market. The basic mechanism used to implement rice price policy have been a floor price, and government controlled international trade in rice to serve as the balance wheel between domestic production and consumption resulting from the respective prices faced by farmers and consumers. Therefore, because of direct government intervention, estimation of acreage supply is complicated by the incidence of several shifts in government agricultural policy during the period of estimation (3) (Guyomard et al. 1996).

In conjunction with the dominant rule of government interventions in rice price policy, this study will employ reduced form autoregressive expectations models (4) (Keeney. and Hertel. 2008). From the models, the acreage supply model will be estimated by assuming that farmers base short-run acreage decision on the ex-ante rational expectation and variance of per-hectare revenue.

The purpose of this study is to examine the effect of government stabilization programs on rice acreage response. To meet this objective a model is developed which is capable of explaining the acreage response, and the impact of that program. The next section briefly discusses the theoretical framework and empirical model involving rice market sub-model and price program model. The model is then estimated using a combination of standard econometric methods and numerical integration techniques.

\section{RESEARCH METHOD}

An easy way to comply with the conference paper formatting requirements is to use this document as a template and simply type your text into it.

The research was conducted in Jambi Province, because this region is one of the producers of rice in Indonesia. And research carried out on 2011. Implementation of the study used survey methods and data drawn from secondary data. 
Data used in this study are the data year 1986-2010 for the province of Jambi. Data from 1986-2010 are used to capture the economic crisis period that varies with the level of economic crisis are high, medium and small.

\section{A. The Acreage Response Functional Form}

Most supply response studies concentrate on the measurement of acreage response due to the high variability of yields. Since production response can always be decomposed of total production, or supply response (Fraser, 1986 and Smith et al. 2009). When between land and new seeds is possible to any significant extent, yield response may be considerable. On the other hand, because actual production levels reflect the influence of uncontrollable variables such as weather, plant disease and infrastructure, basing supply response on production levels is problematic (Villano et al. 2005).

The acreage response equation is

$$
\mathrm{A}_{\mathrm{t}}=\alpha_{0}+\alpha_{1} \Phi_{\mathrm{t}}+\alpha_{2} \lambda_{\mathrm{t}}+\alpha_{3} \mathrm{C}_{\mathrm{t}}+\alpha_{4} \theta_{\mathrm{t}}+\varepsilon_{\mathrm{t}}
$$

where : $\mathrm{A}_{\mathrm{t}} \quad=$ acreage per hectare in year $\mathrm{t}$

$\Phi_{\mathrm{t}} \quad=$ expected gross return in year $\mathrm{t}$

$\lambda_{\mathrm{t}} \quad=$ expected risk in year $\mathrm{t}$

$\mathrm{C}_{\mathrm{t}} \quad=$ input prices in year $\mathrm{t}$

$\theta_{\mathrm{t}} \quad=$ government farm program in year $\mathrm{t}$

$\alpha_{0} \quad=$ intercept

$\alpha_{1}-\alpha_{4}=$ parameters

$\varepsilon_{\mathrm{t}} \quad=$ error term

the variables in equation (7) were defined as follows :

a) The Gross Return Variable $\left(\Phi_{t}\right)$

$$
\Phi_{\mathrm{t}}=\Sigma \mathrm{P}_{\mathrm{t}} \cdot \mathrm{Y}_{\mathrm{t}} \cdot \mathrm{A}_{\mathrm{t}}
$$

where : $\Phi_{\mathrm{t}} \quad=$ expected gross return in year $\mathrm{t}$

$\mathrm{P}_{\mathrm{t}} \quad=$ output price in year $\mathrm{t}$

$\mathrm{Y}_{\mathrm{t}} \quad=$ yield per hectare in year $\mathrm{t}$

$\mathrm{A}_{\mathrm{t}} \quad=$ acreage per hectare in year $\mathrm{t}$

(b) Farmers' Expected Gross Return $\left[\mathrm{E}\left(\Phi_{\mathrm{t}}\right)\right]$

$\mathrm{E}\left(\Phi_{\mathrm{t}}\right) \quad=\alpha_{1} \Phi_{(\mathrm{t}-1)}+\ldots+\alpha_{\mathrm{p}} \Phi_{(\mathrm{t}-\mathrm{p})}+\beta_{1} \varepsilon_{(\mathrm{t}-1)}+\ldots+\beta_{\mathrm{q}} \varepsilon_{(\mathrm{t}-\mathrm{q}}$

where :

$$
\begin{aligned}
\Phi_{(\mathrm{t}-\mathrm{l})}= & \text { gross return per hectare in year (t-p), which } \\
& \text { is an auto-regressive (AR) component, } \\
\varepsilon_{(\mathrm{t}-\mathrm{q})}= & \text { error term of lagged q year, which is a } \\
& \text { moving average (MA) component }
\end{aligned}
$$

(c) Risk Variable $\left(\lambda_{t}\right)$

$$
\lambda_{\mathrm{t}}=\left[\Phi_{\mathrm{t}}-\mathrm{E}\left(\Phi_{\mathrm{t}}\right)\right]^{2}
$$

(d) Farmers' Expected Risk Variable $\left[\mathrm{E}\left(\lambda_{\mathrm{t}}\right)\right]$

$\mathrm{E}\left(\lambda_{\mathrm{t}}\right) \quad=\alpha_{1} \lambda_{(\mathrm{t}-1)}+\ldots+\alpha_{\mathrm{r}} \lambda_{(\mathrm{t}-\mathrm{r})}+\beta_{1} \mathrm{U}_{(\mathrm{t}-1)}+\ldots+\beta_{\mathrm{s}} \varepsilon_{(\mathrm{t}-\mathrm{s})}$

where : $\lambda_{(\mathrm{t}-\mathrm{r})}=$ the risk variable in year (t-r), which is an AR component

$\varepsilon_{(\mathrm{t}-\mathrm{s})}=$ error term of risk associated with production lagged s years, which is MA compenent
In time series analysis, it is important to test the stationary of data. Non-stationary of the time series data has a substantial influence on the final estimated rsults. According to Clark and Spriggs (1989), if a rime series data are not stationary, any shock, even an unexpected policy shock, will cause a permanent response, and the series will not return to the pre shock level without an equal shock in the opposite direction. In contrast, a stationary time series contains only a transitory responses.

The null hypothesis that crop acreage process is a unit root process was tested against the alternative hypothesis that acreage process is stationary around a linear trend. In other test this hypothesis, the equation was defined as follows :

$\delta\left(\mathrm{A}_{\mathrm{t}}\right)=\beta_{0}+\beta_{1} \mathrm{~T}+\beta_{2} \mathrm{~A}_{\mathrm{t}-1}+\beta_{3} \delta\left(\mathrm{A}_{\mathrm{t}-1}\right)+\varepsilon_{\mathrm{t}}$

where :

$\delta\left(\mathrm{A}_{\mathrm{t}}\right)=$ the difference acreage between year $\mathrm{t}$ and year $(\mathrm{t}-1)$

$\mathrm{T}=$ linear time trend

$\mathrm{A}_{\mathrm{t}-1}=$ acreage in year $\mathrm{t}-1$

$\varepsilon_{\mathrm{t}} \quad=$ the error term

$\beta_{0} \quad=$ intercept

$\beta_{1}-\beta_{3}=$ parameters

The null hypothesis, in terms of estimated coefficients of equation (12), can be expressed as follows :

$$
\mathrm{H}_{0}: \beta_{1}=\beta_{2}=\beta_{3}=0
$$

If $\mathrm{H}_{0}$ is not rejected, then, the crop acreage process is a unit root process. Moreover, supply response consists of acreage and yield equations for rice. These equations are specifired linearity and estimated by seemingly unrelated regression. Partial adjustment is assumed and thus lagged acreage is included in the model. The acreage equations are :

$A_{t}=f\left(P_{t-1}^{*}, A_{t-1}, \theta_{t}, T, \Phi_{t}\right)$

where :

$\mathrm{A}_{\mathrm{t}} \quad=$ acreage harvested in year $\mathrm{t}$

$\mathrm{P}^{*}{ }_{\mathrm{t}-1}=$ effective farm price deflated by index the variable cost of production in year $\mathrm{t}-1$

$\theta_{\mathrm{t}}=\mathrm{a}$ varible representing the impact of input subsidy and price support program at year $\mathrm{t}$,

$\mathrm{T}=$ linear time trend

$\Phi_{\mathrm{t}} \quad=$ the risk variable in year $\mathrm{t}$

The estimation acreage equations under risk are estimated by ordinary least sqares. The Durbin-Watson value is used to test the hypothesis. These results will be used to see how much risk has impact on acreage planted and also about the structural elsticity of planted acreage with respect to risk (Lu et al. 2006) .

\section{FINDINGS AND DISCUSSIONS}

The main purpose of this study was to identify the supply response of farmers' decision rules for risk and government policy programs. Expected Utility Profit function is used to estimate the hypothetic parameters. This function is subjected to variables with respect to risk and government policy programs to identify the optimal decision and risk 
efficient strategies. The key functions used to risk analysis are the lagged production function, and government program effectiveness.

\section{A. Estimation of Lagged Production Function}

This study investigated the acreage supply response in existing risk in lagged production function. The parameters of the crop acreage under risk were estimated by the ordinary least squares. In order to test the significance of each parameter, the null hypothesis can be expressed as $\mathrm{H} 0$ : $\beta 1=\beta 2=\ldots=\beta \mathrm{n}=.0$. the results of estimated parameters of acreage response under risk were listed in Table 2. the Durbin Watson analysis showed that the hypothesis that $\beta 1$ $=\beta 2=\ldots=\beta \mathrm{n}=.0$ can be rejected. This implies that at least one of the parameters is not equal to zero.

The acreage response were specified linearly, and estimated at two steps. First, farmers' expected gross revenue per hectare and risk variable were identified. Second, the estimated results were used to predict expected gross revenue per hectare and risk. the expected gross revenue variables were specified as an autoregressive-moving average process of $\Phi$. The result of ARMA $(3,3)$ was expressed as follows:

$\mathrm{E}\left(\Phi_{\mathrm{t}}\right)=\Phi_{\mathrm{t}} *=12,8+0,8 \Phi_{\mathrm{t}-1}+0.01 \Phi_{\mathrm{t}-2}+0.3 \Phi_{\mathrm{t}-3}-0.2 \epsilon_{\mathrm{t}-1}-$ $0.02 \mathrm{C}_{\mathrm{t}-2}-0.3 \mathrm{C}_{\mathrm{t}-3}$

The expected risk variables $(\lambda)$ were specified as an autoregressive-moving average process of $\left(\Phi t-\Phi t^{*}\right) 2$. The result of ARMA $(3,3)$ can be expressed as follows:

$\lambda=12,3-0,5 \lambda_{\mathrm{t}-1}+0.4 \lambda_{\mathrm{t}-2}+0.5 \lambda_{\mathrm{t}-3}-0.03 \mathrm{U}_{\mathrm{t}-1}+0.7 \mathrm{U}_{\mathrm{t}-2}-$ $2.7 \mathrm{U}_{\mathrm{t}-3}$

Moreover, it suggests from empirical results that economic time series are rarely stationary and thus there is no reason that their associated error will be stationary. In order to estimate a unit root (stationary) for acreage response process, the Dickey-Fuller test was used to check the hypothesis that $\mathrm{H} 0: \beta 1=\beta 2=\ldots=\beta \mathrm{n}=.0$. The results can be seen in Table 1.

TABLE I

DiCKEY-FulLER TEST FOR ACREAGE RESPONSE

\begin{tabular}{|l|l|}
\hline & Results \\
\hline F-test & 36,981 \\
Critical Value & 4,03 \\
Judgment & reject $\mathrm{H}_{0}$ \\
Implication & no unit root \\
\hline
\end{tabular}

These results indicated that rice data have no unit roots. So the data for these variables were not differenced before the acreage response was estimated. After the acreage response equation was specified, the estimated parameters were reported in Table 2. From table 2., the positive parameter on the expected gross revenue, $\Phi t^{*}$, was significant at $5 \%$ significance level. This indicates that as farmers' expected revenue for rice increases, the rice acreage will increase.
TABLE III

ESTIMATIONS OF ACREAGE RESPONSE UNDER LAGS

\begin{tabular}{|l|l|l|}
\hline & Parameters & Std. Error \\
\hline Intercept & $-7,6341$ & \\
$\Phi_{\mathrm{t}} *$ & $0,0031 * * *$ & 0,0009 \\
$\lambda$ & $-0,0048 * *$ & 0,0013 \\
$\mathrm{C}_{1}$ & 0,0023 & 0,0067 \\
$\mathrm{C}_{2}$ & 0,0012 & 0,0011 \\
$\theta_{1}$ & $0,0936 *$ & 0,0493 \\
$\theta_{2}$ & $0,0508 * *$ & 0,0241 \\
$\mathrm{~T}$ & 0,0021 & 0,0912 \\
$\mathrm{R}^{2}$ & 0,8923 & \\
$\mathrm{D} . \mathrm{W}$ & 2,7824 & \\
\hline
\end{tabular}

$\Phi \mathrm{t}^{*}=$ expected gross revenue

$\Lambda \quad=$ expected risk

$\theta 1=$ fertrilizer price

$\theta 2=$ pesticide

$\eta 1=$ price support program

ฑं2 = input subsidy

$\mathrm{T}=$ linear time trend

$\mathrm{R} 2=$ adjusted $\mathrm{R} 2$

D.W. = Durbin-Watson statistics

The parameter on the risk variable, $\lambda$, was greater than zero although it is not significant at the $1 \%$ significance level. This indicates that farmers are risk averse, and the risk associated with gross revenue increases, the acreage curve will shift to the left.

The parameter of support price programs, $\eta \dot{1}$, was greater than zero although it is significant at the $10 \%$ significance level. This indicates that support price program have caused any distortions in acreage decisions by shifting the rice acreage response curve to the right.

\section{B. The Impact of Fertilizer and Pesticide Use on Crop Yields}

In order to test trade distorting effect of fertlizer and pesticide subsidy program, it is necessary to analyze the impact of fertilizer and pesticide use on crop yields since this program already showed positive impact on yield increasing and encourage to use.high yield variety that need more fertilizer and pesticide use per hectare in previous year and time trend, and assumed to be linear in its equations:

$$
\mathrm{Yt}=\beta 0+\beta 1 \cdot \mathrm{t}-1+\beta 2 \Phi \mathrm{t}-1+\beta 3 \mathrm{~T}+\epsilon \mathrm{t}
$$

where :

$\mathrm{Yt}=$ rice crop yield in year $\mathrm{t}$

$\mathrm{it}-1=$ fertilizer use per hectare inyear $\mathrm{t}-1$

$\Phi \mathrm{t}-1$ = pesticide use per hectare in year $\mathrm{t}-1$

$\mathrm{T}=$ time trend variable

$\beta 0=$ intercept

$\beta 1-\beta 3=$ parameters

$\mathrm{Et}=$ error term

The OLS method was used to estimate the rice yield parameters. The estimated equation was as follows:

$$
\begin{aligned}
& \delta(\mathrm{At})=4851,3+0,087 \mathrm{~T}+0.371 \mathrm{At}-1+1.081 \delta(\mathrm{At}-1) \\
& (21,9) \quad(0,038) \quad(0,141) \quad(0,2104) \\
& \text { D.W. }=0,5912 \quad \mathrm{R} 2=0,8971
\end{aligned}
$$


From the equation above, fertilizer and pesticide use per hectare had a positive influence on rice yield since its parameter was positive and significant at the 5 percent significance level. This indicates that increased fertilizer and pesticide use increases rice yield. And the parameter on time trend variable was significantly different from zero at the 1 percent significance level. It indicates that technical change has significant impact on rice yield.

The input subsidy program encourages farmers to use more fertilizer and pesticide which increases yields. Since, by using fertilizer, total output of rice is the product of acreage planted. Therefore, the impact of input subsidy program will encourage farmer to increase their output, and shift the output supply curve to the right. Hence, the input subsidy program causes trade distortion by shifting output supply curve to the right.

\section{CONCLUSIONS AND FUTHER RECOMMENDATIONS}

\section{A. Conclusions}

In this study, theoretical and empirical models associated with suply response under risk are reviewed. This study presented a framework for analyzing supply response decisions under risk. The importance of considering risk in rice crop framework was illustrated by simulating the acreage models at various price support levels for rice. The model simulation is used ro evaluate the effectiveness of government programs. And finally to see the impact of risk on supply response.

The first, the lagged production function was postulated for empirical estimation of expectation variables. The estimated parameters showed that risk variables played an important role for farmers in making decisions. The result also showed that farmers are risk averse. Therefore, government policies have to consider risk management, and dynamic considerations.

Finaly, in order to evaluate the effectiveness of this policy especially in government farm program, the risk variables will again give an effect and impact on final result. For instance, eliminating risk will increase the acreage which it means the supply curve will shift to the right.

\section{B. Further Recommendations}

From the above conclusions can be recommended that the meta-profit function can be explained that the factor prices associated with rice plants is crucial for farmers to decide what to plant crops so as to provide benefits. The price was a determining factor, is determined from the market and existing government policies. It is recommended that farmers can overcome the risks it faces, the government is expected to play a role to stabilize the output and input prices and subsidized inputs and price is profitable for farmers.

\section{REFERENCES}

[1] Anonymous, 2011. Jambi dalam Angka. Badan Perencanaan dan Pembangunan Daerah Provinsi Jambi. Jambi

[2] Badan Pusat Statistik (BPS). 2011. Statistik Provinsi Jambi. Jambi

[3] Choi, J.S. and Helmerger P.G. 1993. How Sensitive are Crop Yield to Price Changes and Farm Programs ? Journal Agr. And Applied Economics. 25:237-244.

[4] Clark, J.S. and Spriggs, J. 1989. Policy Implications of Unit Root Nonstationarity in Multiproduct Acreage Response Systems, Department of Agricultural Economics, University of Saskatchewan, Canada.

[5] Fraser, R.W. 1986. Supply Responses, Risk Aversion and Covariances in Agriculture Australian Journal of Agricultural Economics, 35:153-156

[6] Guyomard, H.; Baudry, M. and Carpenter, A. 1996. Estimating Crop Supply Response in the Presence of Farm Programmes: Application to the CAP. European Review of Agricultural Economics 23:401-420.

[7] Lu, W.; Xi, A.; and Ye, J. 2006. Modelling Risk Behavior of Agricultural Production in Chinese Small Households. Poster paper prepared for presentation at International Association of Agricultural Economists Conference, Gold Coast Australia.

[8] Keeney, R. and Hertel T.W. 2008. Yield Response to Prices: Implications for Policy Modelling. Working Paper Dept. of Agricultural Economics Purdue University. Pp. 1-36.

[9] Kolawole, A, O. I Oladele and T. Wakatsuki, 2011. Profitability of different sawah rice production models within lowlands in Nigeria. Journal of Food, Agriculture \& Environment Vol.9 (1): 268 - 274.

[10] McSweeny, W.T. Kenyon, D.E. and Kramer, R.A. 2003. Toward an Appropriate Measure of Uncertainty in a Risk Programming Model. American Journal of Agricultural Economics. 61:87-96

[11] Olwande, J.; Ngigi, M, and Nguyo, W. 2009. Supply Responsiveness of Maize Farmers in Kenya: A Farm-Level Analysis. Paper in International Association of Agricultural Economists Conference, Beijing, China. Pp. 1-17.

[12] Pearson, S. Falcon, W. Heytens, P. Monke, E and Naylor, R. 1991. Rice Policy in Indonesia, Cornel University Press. Ithaca New York.

[13] Polome, P.; Harmigne, O. and Frahan B.H. 2006. Farm-level Acreage Allocation under Risk. Paper in American Agricultural Economics Association Annual Meeting, Long Beach. California USA. Pp. 1-26.

[14] Pope, R.D. 1978. The Expected Utility Hypothesis and DemandSupply Restrictions. American Journal of Agricultural Economics, 60:619-627.

[15] Smith, R.; Duffy, P.; Novak, J.; and Wilson, N. 2009. Supply Response of Crops in the Southeast. Paper in Southern Agricultural Economics Association Annual Meeting, Atlanta, Georgia USA. Pp. $1-20$.

[16] Villano, R.; Donnell, C.J. and Battese, G.E. 2005. An Investigation of Production Risk, Risk Preferences and Technical Efficiency: Evidence from Rainfield Lowland Rice Farms in the Philippines. Working Paper in Agricultural and Resource Economics. University of New England. Pp. 1-24. 